\title{
Motivation and English Achievement in Mexican Teacher Students: A Correlation Study
}

\author{
Alexandra Delgado-Gonzalez ${ }^{1} \&$ Lucia Herrera-Rivas ${ }^{1}$ \\ ${ }^{1}$ Official Normal School of Irapuato, Irapuato, Mexico \\ Correspondence: Alexandra Delgado-González, Official Normal School of Irapuato, Irapuato, Mexico. E-mail: \\ adelgadog@enoi.edu.mx
}

Received: December 6, 2019

Accepted: April 8, 2020

Online Published: February 24, 2021

doi:10.5539/ies.v14n3p96

URL: https://doi.org/10.5539/ies.v14n3p96

\begin{abstract}
The study aimed to measure the correlation between the motivation to learn English as a foreign language and the achievement level in students in the first semester of the Bachelor's degree in Primary Education at a higher education school "Escuela Normal Oficial de Irapuato" (ENOI). These future teachers of basic education are of interest due to the high impact they have on the education of future generations in Mexico. The present study comprised a quantitative non-experimental correlational research. Gardner's attitude/motivation test battery (Gardner, 1985) was used to measure motivation and the Oxford on-line Placement Test scored the students' English level achievement. The motivation results show the high motivation intensity these future teachers have to acquire English as a foreign language, both for integrative and instrumental reasons; the average is 5.79 points out of 7. The English achievement results showed that $67 \%$ of incoming students barely reached an A1 which is less than 20 points out of 120 , even though, it did not include a speaking section which has been reported as one of the most difficult abilities. The Spearman's rank correlation was calculated at 0.2430 using the results before mentioned. Based on these grounded findings, the authors propose focusing on specific learning areas that can better prepare these futures teachers to take advantage of their own students' crucial period.
\end{abstract}

Keywords: motivation, English level, teacher students, Spearman's correlation

\section{Introduction}

\subsection{Introduction of the Problem}

The need to create circumstances which foster global economic activity has had a favorable impact on studying English as a foreign language in México. The country requires its young graduates to be competent users of English to be able to use the language of globalization and actively participate in communication events in their expertise field. However, students' formal contact with English in schools usually begins when they are 11 or 12 years old. Since the 1930s, the national program has included English for 3 years in secondary school, and 3 additional years in preparatory school (SEP, 2019). That adds up to a total of 6 years of taking English as a foreign language. However, the time dedicated to this does not reflect in their achievement. Such a situation has been observed at ENOI, where the vast majority of students from first semester scores very low. According to English First (EF) in recent years, there has been little or no improvement in the proficiency trend in Mexico. EF is one of the largest language schools in the world and it ranks English proficiency by asking international volunteers to answer a standardized on-line English test that assesses the receptive skills of reading and listening comprehension. EF statistics, report that Mexico's English achievement has been consistently low from 2012 to 2019.

The above has led educational authorities to establish a national English language policy to provide high quality English at a younger age, in other words at initial basic education. According to the National English Program only $22 \%$ of public schools have English teachers, and at least 80,000 additional English teachers are required to provide English classes in preschool, primary and secondary schools. There are not enough English teachers to cover the increasing demand (Consejo Nacional de Evaluación de la Política de Desarrollo, 2013).

At the same time, the young population in Mexico has identified the need to communicate in English. Being able to do so in this country has proven to be very helpful to increase the quality of life, including a high correlation with higher salary jobs. Learning English as a foreign language is a goal for a large number of people in Mexico. 
Nevertheless, to this day it remains a privilege only a few can afford to pay in private institutions (Intelligence, 2015).

Successful learning requires motivated students, and as mentioned by the social cognitive theory, motivation is one of several factors that contribute to develop a proper learning strategy and has an important role in self-regulation. Motivation has a lot of implications in educational practice, it is considered an internal state that drives us to action, keeps us engaged in a particular activity and directs us in a specific path (Ormrod, 2012).

\subsection{The Significance of the Study}

This study is significant because it is aimed at providing an answer to whether or not motivation to learn English is the main factor impacting the English level of future preschool and primary teachers. This is of paramount importance considering these future teachers will be working in the basic education level with young students in the most effective age for English instruction. It has been observed that when very young learners are exposed only to spoken language for a few years, they are able handle it more naturally (Cameron, 2001). The implication here is that preschool and primary teachers with sufficient English level will be able to provide some input to their young students.

\subsection{The Research Problem}

A need to innovate the teaching of English has turned into one of the country's educational priorities. A range of variables is to be considered within which we can mention the amount of input and initial age of contact with the language. In terms of the later, the new program at national teachers' training schools known as "Escuelas Normales" (EN) went from 4 to 6 of hours of English classes per week. The Common European Framework of Reference for language (CEFR), establishes 6 levels; A1, A2, B1, B2, C1, and C2. To advance from one level to another an average of 200 hours of English classes is the time a person needs, (Knight, 2018).

Regarding age, English needs to be introduced at an earlier stage, in other words, preferably in preschool or as a second option, in primary. Some authors, including Bum et al. (2017) consider before the age of twelve as the best moment to learn a foreign language mentioning that the L2 learning process for adults entails different, more intensive work (Snow \& Hoefnagel-Höhle, 1978). In addition to the latter, Nouri (2014) considers that there are sensitive periods, during which an individual can acquire certain aspects of language with greater ease than at other times. The earlier a person is exposed to the target language, the higher the possibility of achieving a higher outcome or 'ultimate attainment'. Cruz (2017) concludes that a disadvantage for a person who acquires a foreign or L2 language during adulthood is that they may never reach a state of proficiency which is near native. Students, who study a teaching degree at the preschool or primary level at ENOI, will be able to take English to young learners ages 3 to 12 in public schools.

Since there are currently only a few public schools where children are taking regular and sufficient, high quality English classes, exposure to English during the early years remains a realm of unexplored potential (Consejo Nacional de Evaluación de la Política de Desarrollo, 2013). To increase the percentage of students receiving English class, the federal government announced a strategy to recruit the best 1000 teachers in the country with a vision that within the following 20 years Mexican citizens could graduate from basic education speaking English and with an internationally recognized certification. One of the objectives of this strategy is to strengthen English at EN, whose main purpose is to educate teachers. To achieve this goal a rigorous process was launched to hire English teachers and after the screening, 645 full-time teachers were incorporated to EN (SEP, 2017).

For these reasons, teaching English to future teachers in EN in the country becomes a paramount endeavor as they have had previous exposure to English, but not during their early years of education, and not in sufficient quantity to increase their confidence (Trujillo et al., 2019). Therefore, the action to be taken is to improve their English level in 7 semesters, 6 hours per week. A salient consideration is that L2 learning is driven in a very powerful way by the learner's motivation (Gardner, 2010). Therefore, each student is a key factor in achieving the goal of learning English as a foreign language.

Moreover, we became interested in exploring the motivation levels to learn a L2 in the very specific population of individuals studying a teaching degree during the initial stage of the program. The hypothesis is that there is a correlation between motivation and the level of achievement the students have in English at the beginning of their Bachelor's Degree for Primary Education.

The purpose of the study is to measure and analyze the correlation between the motivation to learn English of the students and their English level, at the beginning of their teaching program. 


\subsection{The Statement of the Problem}

Mexican students are in dire need of high-quality English instruction, basic education teachers are currently not qualified to provide such instruction, and therefore we are interested in knowing the relationship between motivation and English level in teacher students so we can develop strategies to improve the level of these students.

\subsection{The Research Questions Are}

- What is the teacher trainees' level of motivation to learn English?

- What is the English level of teacher trainees?

- Is there a correlation between the motivation and the English level variables among teacher trainees?

\subsection{Hypothesis}

The research hypothesis is that students with a higher English level are also the ones who exhibit higher motivation to learn English. In other words, there is a positive correlation between motivation and English level measures on students.

\subsection{Objectives}

The objectives of this research are:

- to measure the motivation to learn English expressed by students.

- to assess the initial English achievement before incorporating to the higher education teaching program.

- to identify if there is a correlation between these two variables. In this study we consider motivation to be the independent variable and the English achievement to be the dependent one.

\subsection{Literature Review}

Regarding the study of motivation and achievement, Gardner (1985) has made important contributions; in particular Gardner's socio educational model of second language acquisition introduces the idea of needing more than just cognitive ability to learn a second language, mentioning affective factors as mayor influence in the acquisition process; such as intrinsic and extrinsic motivation as well as anxiety. This model highlights the important social implications second language has on the life of the learner (Gardner \& Lalonde, 2012). In this model, motivation is defined as the combination of effort and desire a person has to learn a second language. In other words, it measures the amount of work and effort made by a person because of the desire to acquire the second language and the satisfaction obtained during the activity (Gardner, 1985). There are two main parts of motivation; instrumental, and integrative. The first is learning due to a practical purpose, and the second is having motivation for personal growth and to integrate into the $\mathrm{L} 2$ culture.

Another concept to be defined for this work is attitude. Attitude is viewed as having cognitive, affective and conative components. Attitudes are viewed as "an evaluative reaction to some referent or attitude object, inferred on the basis of the individual's beliefs or opinions about the referent" (Gardner \& Lalonde, 2012).

Following Gardner's substantive lead, other authors have agreed on the importance of the motivation element in the L2 learning outcome; some studies have been carried out in very different places and with different participants including middle school students and higher education students in a variety countries with different L1 and different majors (Lai, 2013; Guerrero, 2015; Rifai, 2010; Mahdavi-Zafarghandi et al., 2012).

Motivation to learn English or lack thereof has been studied at the higher education level in various countries, in a particular study in Malaysia (Azar \& Tanggaraju, 2020), the authors found that opportunities to visit English speaking countries should be given to teachers and students to promote motivation. Other authors have proposed using videogames as a motivation tool to learn a second language (L2) particularly thorough storytelling (Prestopnik, 2016).

Some studies have considered the absence of motivation as a main factor in specific problems when people learn a second language, in particular, its role on fossilization and conclude that "there is an evident correlation between strong levels of motivation and linguistic achievement" (Font Sanclimens, 2018). The role of emotions and motivation is particularly impactful on specific abilities, such as speaking, in an Iranian study (Khajavy et al., 2018) the authors found that positive classroom environment as well as enjoyment during class, both reduced anxiety in students and motivated their willingness to communicate.

Even though, the AMTB has been used and validated previously in Mexican higher education (Sandoval-Pineda, 2011), scarce work with this particular population has been found by the authors (Mora Vázquez et al., 2011) 
(Cocca et al., 2017). Therefore, our research focuses on measuring motivation and English achievement by students in teaching degrees at ENOI because of the important role they will play in the country's educational system.

We include a table of abbreviations to facilitate the further reading.

Table 1. Abbreviation

\begin{tabular}{ll}
\hline Abreviation & Meanning \\
\hline AMTB & Attitude/Motivation Test Battery \\
CEFR & Common European Framework of Reference for Languages \\
EN & Escuelas Normales \\
ENOI & Escuela Normal Oficial de Irapuato \\
\hline
\end{tabular}

\section{Methodology}

The widely known Attitude/Motivation Test Battery (AMTB) used in this study was designed by Gardner. It is a psychometric tool that measures attitude and motivation towards learning L2 as expressed by participants (Gardner, 1985). The AMTB was initially used in Canada to measure attitude and motivation towards French as L2. This battery is divided into nine subscales as seen in Table 2 .

Table 2. AMTB subscales

\begin{tabular}{cl}
\hline Subscale & Name \\
\hline 1 & Interest in foreign languages \\
2 & Motivational intensity to learn English \\
3 & Teacher evaluation \\
4 & Attitude towards learning English \\
5 & Attitude towards English speaking people \\
6 & Integrative orientation \\
7 & Desire to learn English \\
8 & English course evaluation \\
9 & Instrumental orientation \\
\hline
\end{tabular}

Several factors regarding motivation are measured such as desire and attitudes to learn English (Shahbaz \& Liu, 2012). The objective of the battery is to quantitatively measure the main factors that influence L2 learning in the socio-educational model. Among the subscales measured in the AMTB, it is important to define integrative orientation; it refers to how open the person is to the culture of the L2 speaking People, in the particular case of this study, it is measured regarding attitude towards English speaking people. Another subscale worth defining is instrumental orientation which refers to how much the learner thinks L2 is useful in a person's life, particularly in work related environments (Gardner \& Lalonde, 2012).

In this study, second language achievement is viewed in a traditional manner, referring to measuring grammar, vocabulary and use of English as the main factors to take into consideration. Communicative competence is not measured due to the nature of the test, which does not include a speaking part in the evaluation.

\subsection{Research Design, Instruments and Procedures}

This research is quantitative non-experimental correlational considering that all the measurements were done at one point in time, the initial week from the first semester of the program (Johnson \& Christenen, 2019).

To evaluate the motivation to learn English expressed by the students, the authors decided to use the AMTB developed by Gardner (1985) considering the nine main categories as stated in Table 2. To apply the AMTB, the questionnaire was digitalized on Google Forms and sent to students through their institutional e-mail. The answers to the questions are rated on a Likert scale 1 to 7 , where 7 demonstrate the highest level of motivation.

The assessment tool selected to evaluate the students' English achievement was the On-line Oxford Placement Test (Press, 2018). It is important to mention that the test is part of the standard procedures that newcomer students go through during the initial week of the program.

The test results score between 0 and 120 points, assigning a minimum and maximum number of points per level 
from the Common European Framework of Reference, as described in Table 3. It consists of two parts; the first one is Use of English with approximately 30 questions including vocabulary, grammar and the understanding of meaning in a conversation. The second part of the on-line test measures the listening skill, in this part; the comprehension of a conversation is evaluated with approximately 15 questions. The validation for the Oxford Online Placement Test was done through an extensive research study including 10,000 students from 42 countries (Press, 2018).

Table 3. English placement test levels

\begin{tabular}{cc}
\hline Level & Score range \\
\hline$<$ A1 & 0 \\
A1 & $1-20$ \\
A2 & $21-40$ \\
B1 & $41-60$ \\
B2 & $61-80$ \\
C1 & $81-100$ \\
C2 & $>100$ \\
\hline
\end{tabular}

\subsection{Participants}

This research was carried out at ENOI. The participants of this research were first semester students in the Bachelor's Degree in Primary Education. The total number of students and the percentage of males and females, as well as the average age in this study, are presented in Table 4, where the total number of participants was 92 among which 63 , equivalent to the $69 \%$ were females while 29 , equivalent to a $31 \%$ were males. Their average age was 19.6 years old. All the participants in this study voluntarily answered the motivation instrument, whereas the English achievement tool was obligatory for all of them as it was required by the institution.

Table 4. The participants

\begin{tabular}{cccc}
\hline Students & Number & Percentage & Age average (years) \\
\hline Total & 92 & 100 & 19.6 \\
Female & 63 & 69 & 19.5 \\
Male & 29 & 31 & 19.6 \\
\hline
\end{tabular}

Using the motivation results as well as the English achievement results, Spearman's rank correlation coefficient was calculated to see if there is a correlation between these two factors. After that, the correlation was evaluated using the English achievement level results and each of the categories the motivation test measures.

The Spearman's rank correlation coefficient rho (Snell \& Sprent, 1995) is a correlation measurement similar to Pearson's correlation coefficient. It is used for categorical data (Begg, 2009), this means that the data being handled is not continuous but it can be separated in categories and if these categories are ordered then they are considered ordinal data, as is the case of the data being handled in this study.

Once the Spearman's rho is calculated, it can be established whether there is a correlation between the variables, meaning rho is different from zero, and if this correlation is positive, negative, strong or weak. The values of the Spearman's rank coefficient may vary between -1 which means the variables are negatively correlated to 0 showing no correlation and then to 1 meaning the variables are positively correlated (Cohen et al., 2003).

The level of statistical significance is being expressed through the p-value, considering that the smaller the p-value is, the stronger the evidence to reject the null hypothesis (Walpole et al., 2012). Considering this work is non experimental, no intervention or experimental manipulation was carried out.

\section{Results}

For the total of 92 students, the average motivation resulted in 5.79 out of 7 as shown in Table 5, corresponding to an $82.72 \%$. Table 4 presents the mean, standard deviation, kurtosis and skewness of the nine subscales measured by the AMTB, where the subscale attitudes towards English speaking people is the one with the lowest measurement at 5.05 out of 7 , and the subscale interest in foreign languages is the one with the highest measurement at 6.20 out of 7 . 
Table 5. AMTB subscales results.

\begin{tabular}{llcccc}
\hline & Subscale & mean & sd & kurtosis & skeweness \\
\hline 1 & Interest in foreign languages & 6.20 & 0.87 & 12.24 & -2.58 \\
2 & Motivational intensity to learn English & 5.93 & 1.00 & 5.36 & -1.92 \\
3 & Teacher evaluation & 5.94 & 1.18 & 2.59 & -1.66 \\
4 & Attitude towards learning English & 6.12 & 1.05 & 6.38 & -2.14 \\
5 & Attitudes towards English speaking people & 5.05 & 1.07 & 0.87 & -0.47 \\
6 & Integrative orientation & 6.19 & 0.98 & 8.08 & -2.31 \\
7 & Desire to learn English & 6.04 & 0.88 & 3.03 & -1.56 \\
8 & English course evaluation & 5.60 & 1.16 & 2.36 & -1.36 \\
9 & Instrumental orientation & 5.47 & 1.05 & 1.63 & -1.11 \\
& Total & 5.79 & 0.80 & 3.81 & -1.57 \\
\hline
\end{tabular}

Furthermore, the results from Table 5 clearly show the results for mean, standard deviation, kurtosis and skewness for each subscale, where the mean and standard deviation are measurements of central tendency. Additionally, the kurtosis and skewness indicate the shape of the data distribution. Regarding the latter factors, the skewness values indicate the degree of asymmetry of the distribution, in the case of the data measured in this study, it is negatively skewed.

On the other hand, the average English achievement came to 33.06 out of 85 , corresponding to a $38.9 \%$ of the total possible in the achievement in English category, detailed English achievement results presented by level in Table 6 . Noteworthy results are that not a single student reached the B2 level, only 2 reached B1 and the vast majority is in the A1 (basic) level.

Table 6. English achievement results

\begin{tabular}{ccc}
\hline Level & Number of students & Percentage \\
\hline A0 & 1 & 1.08 \\
A1 & 61 & 66.3 \\
A2 & 28 & 30.4 \\
B1 & 2 & 2.17 \\
B2 & 0 & 0 \\
\hline
\end{tabular}

Moreover, the Spearman's rank coefficient which measures the correlation between the measured variables, motivation to learn English and English achievement in future Primary school teachers, indicates there is correlation; however the intensity is low (Lewis-Beck et al., 2004) with a p-value of .01955, therefore making this correlation statistically significant.

Table 7. Correlation between motivation and English achievement

\begin{tabular}{ccc}
\hline & Rho & p-value \\
\hline Spearman's rank correlation & 0.2430 & $<0.01$ \\
\hline
\end{tabular}

The total results reported in Table 5, clearly show a high level of motivation (5.7 out of 7). Regarding the English achievement reported in Table 6, it can be seen that most of the students $(66.3 \%)$ are in the first level accepted by the CEFR that is A1. This level comprises people who are beginners, and can only understand basic expressions for the satisfaction of important needs and are able to carry out very simple interactions. Table 6 also registers the fact that in the results analyzed none of the students reached a B2 level.

On the correlation measurement, where Spearman's rank coefficient was analyzed, the results are shown in Table 7. The latter illustrates the fact that there is a correlation between the motivation level and the English achievement, however the strength is between low and moderate. This phenomenon occurs, specifically because of the high levels of motivation and relatively low English achievement. 


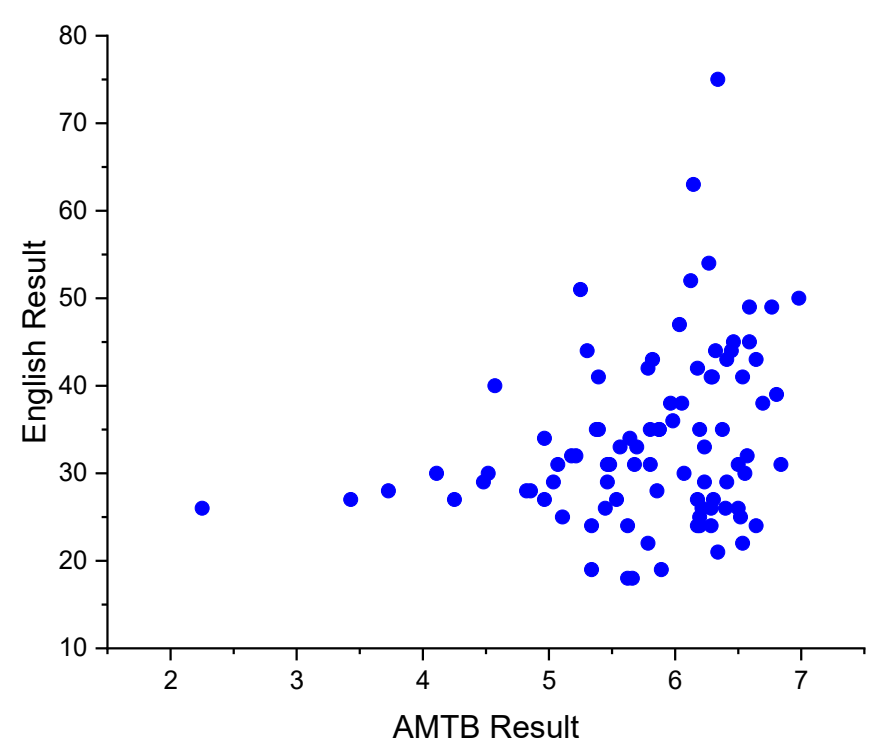

Figure 1. Motivation and English level of the participants

Regarding Figure 1, each dot represents a participant with their particular motivation level and English level. From this scatter plot it is possible to notice that teacher trainees are highly motivated to learn English, and that does not always translate to high a English level, however, a correlation is noticeable, in accordance with the results presented in Table 7 .

\section{Discussion}

Considering the high impact of so-called sensitive periods for language acquisition during the years of preschool and primary education, we believe the future of basic education teachers ideally should have intensive training in both English achievement and (if possible) English Language Teaching training. This dual training would be ideal for the educational goals a country like Mexico has regarding English Language Acquisition.

The results obtained in this work show the high motivation intensity these future teachers have to acquire English as a foreign language, both for integrative and instrumental reasons. Furthermore, they exhibit high interest and desire to learn English. The authors consider this to be a golden opportunity to expose these future teachers to a variety of options to increase their English achievement, in particular, regular, high quality English classes and opportunities to participate in exchange programs to visit English speaking countries.

The second part of the study regarding English achievement, demonstrates the fact that in this particular school over $67 \%$ of incoming students reach an A1 level or less, even taking into account that the evaluation does not measure the speaking ability, which has been reported as one of the most difficult to achieve. Most of the participants reported having at least 6 years of previous English classes, per under the Mexican national education plan, which includes English classes from ages 12 to 18 . But almost none of them reported having English classes during more sensitive age period from 3 to 12 .

The low intensity of the correlation between the measured variables indicates the disparity in the high motivation to learn English and the low performance in the English achievement test of the participants, this is suspected to be due to the fact that the participants start to become aware of the possible benefits of English until their professional life, so their motivation to learn it is high, however since exposure to English during the sensitive periods is rather scarce, their English level remains low.

Therefore, the lack of opportunity to study the language and the little exposure during sensitive periods can be considered as two of the main possible reasons why the phenomenon is occurring. These results support the proposal that English must be taught in the early stages of education, particularly to teachers involved in basic education. Based on the results, the high importance and necessity of teaching English in the early education stages comes evident. For these reasons, it is critical to increase the training in two main aspects regarding 
English; the first is the development of basic English skills, especially oral skills because this is an aspect that needs reinforcement, and the second aspect that requires training is regarding English teaching training, because even though, their teaching original expertise will not be English, they will be able to take advantage of their students' sensitive period to expose them to some English activities during their classroom practice.

It is important to mention that the participants of this research will graduate in as short as two years, and begin their practice training in approximately four years, they will be in charge of a basic education classroom. Hence, measuring the motivation these students have to learn English is of particular interest considering the ripple effect they can have on their future students. Therefore, the work done with these students in the development of English skills will very soon have results impacting children in a sensitive period.

\section{References}

Azar, A. S., \& Tanggaraju, D. (2020). Motivation in second language acquisition among learners in malaysia. Studies in English Language and Education, 7(2), 323-333. https://doi.org/10.24815/siele.v7i2.16506

Begg, M. D. (2009). An introduction to categorical data analysis (2nd ed.). Statistics in Medicine, 28(11), 1643-1643. https://doi.org/10.1002/sim.3564

Bum, S., Park, J., Moon, Y., Louis, M., \& Paul, D. (2017). Learning a Foreign Language in Adulthood using Principles of Neuroscience. ARC Journal of Neuroscience, 2(1), 10-13. https://doi.org/10.20431/2456-057x.0201003

Cameron, L. (2001). Teaching Languages to Young Learners. In Teaching Languages to Young Learners. Cambridge University Press. https://doi.org/10.1017/cbo9780511733109

Cocca, M., Pérez García, J. A., Zamarripa, J. I., Demetriou, Y., \& Cocca, A. (2017). Psychometric parameters of the attitude/motivation test battery instrument in a Mexican environment. Revista de Psicologia Del Deporte, 26(July), 149-155.

Cohen, J., Cohen, P., West, S. G., \& Aiken, L. S. (2003). Applied multiple regresion/correlation analysis for the behavioral sciences (3rd ed.). LAWRENCE ERLBAUM ASSOCIATES, PUBLISHERS.

Consejo Nacional de Evaluación de la Política de Desarrollo. (2013). Programa Nacional de Inglés en Educación Básica Resultados Población Objetivo : Cobertura Análisis del Sector Análisis del Sector.

Cruz, A. (2017). A Review of the Neuroscience of Second Language Acquisition. Senior Honors Theses, 559, 39. Retrieved from http://commons.emich.edu/honors/559

Font Sanclimens, A. (2018). Challenging Fossilization: The Role of Motivation in Second Language Acquisition (Issue June). Universitat Autonoma de Barcelona.

Gardner, R. C. (1985). Social psychology and second language learning: The role of attitudes and motivation. In System (Vol. 15, Issue 2, pp. 236-240). https://doi.org/10.1016/0346-251x(87)90081-9

Gardner, R. C. (2010). Motivation and Second Language Acquisition: The Socio-Educational Model. Peter Lang.

Gardner, R. C., \& Lalonde, R. N. (2012). Second Language Acquisition: A Social Psychological Perspective. The Oxford Handbook of Applied Linguistics (2nd ed.). https://doi.org/10.1093/oxfordhb/9780195384253.013.0014

Guerrero, M. (2015). Motivation in Second Language Learning: A Historical Overview and Its Relevance in a Public High School in Pasto, Colombia. How, 22(1), 95-106. https://doi.org/10.19183/how.22.1.135

Intelligence, E. (2015). English in Mexico: An examination of policy, perceptions and influencing factors ENGLISH LANGUAGE LEARNING ANALYSIS 23 ENGLISH LEARNING MOTIVATIONS 28. May.

Johnson, R. B., \& Christenen, L. (2019). Educational Research :Quantitative, Qualitative, and Mixed Methods Approaches. In SAGE Publications, Inc.

Khajavy, G. H., MacIntyre, P. D., \& Barabadi, E. (2018). Role of the Emotions and Classroom Environment in Willigness to Communicate. Studies in Second Language Acquisition, 40(3), 605-624. https://doi.org/10.1017/S0272263117000304

Knight, B. (2018). How long does it take to learn a foreign language. In Experience Better Learning.

Lai, H. Y. T. (2013). The motivation of learners of english as a foreign language revisited. International Education Studies, 6(10), 90-101. https://doi.org/10.5539/ies.v6n10p90

Lewis-Beck, M. S., Bryman, A. E., \& Futing Lio, T. (2004). The SAGE encyclopedia of social science research 
methods. SAGE Publications. https://doi.org/10.4135/9781412950589

Mahdavi-zafarghandi, A., Linguistics, A., English, T., Language, F., \& Jodai, H. (2012). Attitudes toward English \& English learning at an Iranian Military A preliminary survey (pp. 1-39).

Mora Vázquez, A., Trejo Guzmán, N. P., \& Roux Rodríguez, R. (2011). A small scale investigation into mexican university students' language learning motivation. Actualidades Investigativas En Educación, 10(1). https://doi.org/10.15517/aie.v10i1.10095

Nouri, A. (2014). Cognitive Neuroscience of Foreign Language Education: Myths and Realities. Research in English Language Pedagogy, 5(0), 40-47.

Ormrod, J. E. (2012). Human Learning (6th ed.). Pearson.

Press, O. U. (2018). Oxford English Testing. Retrieved from https://www.oxfordenglishtesting.com/DefaultMR. aspx?id=3034\&menuId $=1$

Prestopnik, N. (2016). Games, Stories and Language: Motivating Second Language Acquisition with Play. International Journal of Designs for Learning, 7(3), 72-87. https://doi.org/10.14434/ijdl.v7i3.20051

Rifai, N. A. (2010). Attitude, motivation, and difficulties involved in learning the English language and factors that affect motivation in learning it. Procedia-Social and Behavioral Sciences, 2(2), 5216-5227. https://doi.org/10.1016/j.sbspro.2010.03.849

Sandoval-Pineda, A. (2011). Attitude, Motivation and English Language Learning in a Mexican College Context. University of Arizona. Retrieved from https://books.google.com.mx/books?id=sO2WnQAACAAJ

SEP. (2017). Comunicado 184.- Presenta Nuño Mayer la Estrategia Nacional de Inglés, para que México sea bilingüe en 20 años. Retrieved from https:/www.gob.mx/sep/prensa/comunicado-184-presenta-nuno-mayer -la-estrategia-nacional-de-ingles-para-que-mexico-sea-bilingue-en-20-anos

SEP. (2019). Planes y programas. Retrieved from https://www.planyprogramasdestudio.sep.gob.mx

Shahbaz, M., \& Liu, Y. B. (2012). Complexity of L2 Motivation in an Asian ESL Setting. PORTA LINGUARUM. https://doi.org/10.30827/Digibug.14699

Snell, J., \& Sprent, P. (1995). Applied Nonparametric Statistical Methods. In Journal of the Royal Statistical Society. Series A (Statistics in Society) (Vol. 158, Issue 2). https://doi.org/10.2307/2983315

Snow, C. E., \& Hoefnagel-Höhle, M. (1978). The critical period for language acquisition: Evidence from second language learning. Child Development, 49(4), 1114-1128. https://doi.org/10.2307/1128751

Trujillo, S., Delgado González, A., \& Herrera Rivas, L. (2019). El impacto de la estrategia nacional de inglés en su primer semestre de implementación en la Escuela Normal Oficial de Irapuato. Congreso Nacional de Investigación Sobre Educación Normal, 1-14.

Walpole, R. E., Myers, R. H., Myers, S. L., \& Ye, K. (2012). Probabilidad y estadística para ingeniería y ciencias (9th ed.). Pearson.

\section{Copyrights}

Copyright for this article is retained by the author(s), with first publication rights granted to the journal.

This is an open-access article distributed under the terms and conditions of the Creative Commons Attribution license (http://creativecommons.org/licenses/by/4.0/). 